\title{
Practical Scandinavianism - the journal Grafisk Revy and its relation to New Typography
}

abstract Between 1930 and 1936 the journal Grafisk Revy [Graphic Revue] was published jointly by Denmark's, Norway's and Sweden's national typographers' unions (Dansk TypografForbund, Norsk Centralforening for Boktrykkere and Svenska Typografförbundet respectively). Responding to interest in raising standards and awareness in the trade, sharpened by debates surrounding New Typography's emergence in Scandinavia, the journal's editors argued a 'domestic' counterpoint to foreign printing journals like the German Typographische Mitteilungen [Typographic News] was needed to discuss typographic composition and other 'technical' matters. In doing so Grafisk Revy adopted a gently favourable stance towards New Typography and played an important role in spreading its ideas to Scandinavian typographers. Its position as a Scandinavian journal was reinforced by expressively drawing upon a tradition of Scandinavianism - and as such it can be seen as a self-conscious attempt to unify the three nations' typographers. The trade's increased interest in educational matters also led to the establishment of Typografernes Fagtekniske Samvirke [The Typographers' Trade-Technical Cooperative], an educational branch of the Danish typographers' trade union. This organisation eventually caused Grafisk Revy to split into three national publications - for reasons less related to conflicting ideas of identity than to organisational politics and diverging motivations for international cooperation.

new typography, trade unions, trade journals, scandinavianism, 1930s

\section{Introduction}

\section{Practical and workers Scandinavianism}

Described by its editors as an experiment in "practical Scandinavianism", Grafisk Revy selfconsciously placed itself in a Scandinavianist tradition (Anon. 1931a: 1). Ruth Hemstad, who has written a recent study on the subject, defines Scandinavianism as a number of distinct movements taking place between 1830 and 1915 based on the perceived notion that the Scandinavian peoples make up a unique community due to similarities in language, culture and history. It can be divided into the main categories 'political' and 'cultural', Political Scandinavianism was concerned with the creation of a Scandinavian state, but became spent when Sweden-Norway failed to provide the military support it had promised Denmark during 1864 S Second Schleswig War. Cultural Scandinavianism, which had a much longer influence, instead advocated a closer collaboration between the three countries' peoples with the aim of creating a unified cultural unit (Hemstad 2008: 21). It was also occasionally known as Practical Scandinavianism, the term used in Grafisk Revy. 
The dissolution of the Swedish-Norwegian union in 1905 cooled inter-Scandinavian relations, but after the First World War these gradually thawed again and increased cooperation followed (Hemstad 2010: 185-186). The interwar period also saw the Social Democratic parties rise to power, forming governments from the late 1920s onwards (Denmark in 1929, Sweden in 1932 and Norway in 1935). In 1934 the Swedish prime minister Per Albin Hansson (1885-1946) used the term "Workers Scandinavianism" to describe the early cooperation between the three nations' labour movements during the late 19th and early 20th centuries (Grass 2002: 11).

Two of Grafisk Revy's contributors were actively involved in the labour movement even at this early stage. Nils Wessel (1866-1940), the journal's future editor, and the Dane L. Chr. Nielsen were both members of Malmö Socialdemokratiske Förening [Malmö Social Democratic Association]. Malmö was an important centre for the early labour movement in Sweden, and the association was the first of its kind in the country (Billing, Olsson \& Stigendal 1992: 272). In 1890 Nielsen published a pamphlet titled Finnas f.n. några utsigter för ett skandinaviskt Typografförbund? [Are there any possibilities at present for a Scandinavian typographers' union?], where he argued that such a union would be better equipped to make demands of employers than national ones (Nielsen 1890: 12-14). This shows his longstanding personal investment to Workers Scandinavianism, and it is likely he and Wessel in Grafisk Revy were taking advantage of a renewed atmosphere of Scandinavian cooperation to rekindle the movement they had been part of in their youth.

\section{Launched during the modernist breakthrough}

The first issue of Grafisk Revy was published in May 1930, the same month as the Stockholm Exhibition opened. The exhibition is widely considered functionalism's "breakthrough" moment in Swedish architecture and design (Råberg 1970). However, the printed matter on display only tentatively reflected this. Especially the book section continued to be "dominated by traditional items of fine printing" (Gram 2006: 57). The exhibition's posters and signage, its most high-profile items of typography, did show a modernist influence. However, these were designed by Sigurd Lewerentz (1885-1975), an architect. Typographers were strongly rooted in their printing culture, with many devoted to the Neoclassical style that had won them accolades at the 1925 Paris Exhibition (Exposition Internationale des Arts Décoratifs et Industriels Modernes) and which they considered particularly 'Swedish'. Despite this, some members of the community -like Hugo Lagerström (1873-1956)- argued the modernist typography that had been developing in central Europe since the mid-1920s should be engaged with.

Modernist views were influenced by the German typographer and theorist Jan Tschichold's (1902-1974) writings on New Typography. In 1925 Tschichold had edited a special edition of Typographische Mitteilungen titled elementare typographie [elemental typography], which included two pieces of his own writing. The first of these, Die neue Gestaltung [The New Design], traced New Typography's roots in abstract art - explaining that it "is founded on the knowledge imparted by the logically consistent work of Russian Suprematism, Dutch Neo-Plasticism and especially Constructivism" (Burke 2007: 193). The second was a manifesto, also titled elementare typographie, containing a series of practical principles for the construction of New Typography. These can briefly be summarised as a preference for photography over illustration, sans-serif over serif or blackletter type, the use of single 
case, asymmetrical rather than symmetrical type-arrangement and the active use of the unprinted white paper surface in composition (Tschichold 2007: 311).

The manifesto was known in Scandinavia from a Swedish translation published by Lagerström in his journal Nordisk Boktryckarekonst [Nordic Printing Art] in 1927. At this point he had yet to embrace what he called "the new style". The translation formed part of an article warning against Tschichold's ideas, urging the readers instead to stay true to the Swedish Neoclassical style (Lagerström 1927: 136). However, over the next few years he would gradually moderate his views until finally coming out in favour in December 1929, announcing that "the new style doubtlessly contains new forms of typographic expression
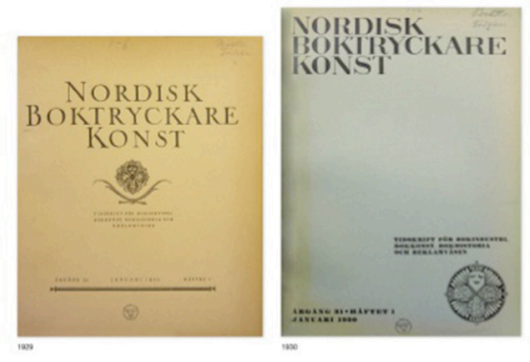

Figure 1.

Nordisk

Boktryckarekonst: cover designs for 1929 and 1930.

worth studying and testing" (Lagerström 1929: 457).

Introduced into this context it is not surprising that New Typography filled a significant proportion of Grafisk Revy's first issue. However, that the articles should show a gentle acceptance of Tschichold's views was not inevitable, and telling of the journal's outlook. Wessel's Den nya riktningen inom typografien [The new direction in typography] provided a brief summary of 'Growth and nature of the new typography', the first section of Tschichold's Die neue Typographie [The New Typography] (1995: 11-108). Another article, by Danish typographer Viggo Hansen, claimed elementare typographie to be a useful "new variation" in typographic design (1930: 13).

\section{The design of Grafisk Revy}

Though it also promised a section devoted to "agitation", Grafisk Revy was the first journal published by any of the Scandinavian typographers' unions to deal mainly with "technical" issues (Redaktionen 1930: 1). Because typographers were responsible for laying out as well as producing items of typography, this included considerations of visual design. Similar journals had been published elsewhere in Europe for several years and some were named as influences: Typographische Mitteilungen, and two other 'Graphic Revues' the Austrian Graphische Revue and the Yugoslav Grafička Revija. According to the editors such journals had succeeded in establishing "an increasingly large influence on typographic styles" in the Scandinavian countries, and they envisaged Grafisk Revy as a 'domestic' counterpoint to these (The editors 1930: 1). In keeping with its Scandinavian profile no more than two issues were designed and produced by any one union before responsibilities were passed on to the next in turn. Each issue had a unique cover, and the internal text pages were redesigned with each hand-over.

Most page designs showed only a moderate application of Tschichold's ideas. However, there were exceptions - and these didn't go unnoticed by contemporaries. The printers' journal Norsk Trykk [Norwegian Printing] described the second issue of 1931 as "the 
theme 3

identity

Figure 2.

First cover 1930 and last cover 1936

Figure 3.

Spread from: Paul

Schmidt,

Fotografi i

moderne typografi. strand 1

design process and pratice

most radical...yet accomplished by a [typographer's] trade journal in Scandinavia", adding "Jan Tschichold couldn't have done better" (Anon. 1931b: 77). Another example which came particularly close to an orthodox application of elementare typographie principles was the German-born Danish typographer Paul Schmidt's article Fotografi i moderne Typografi [Photography in modern typography] published in the following issue. Using the Hungarian artist László Moholy-Nagy's (1895-1946) term 'typophoto' he discusses how to best use the photograph in typographic composition. Schmidt probably also stood for the article's design - strikingly different to the more conventional one used for the rest of the issue. A personal involvement from Tschichold came in 1936 with the journal's final panScandinavian issue. He designed most of its pages, ads and wrote an article on proportions in New Typography which concluded: "The design of this issue, the examples in this article and most of the ads serve as illustrations to my explanations. May they contribute to spreading the New Typography even further in the Nordic countries." (Tschichold 1936: 16).
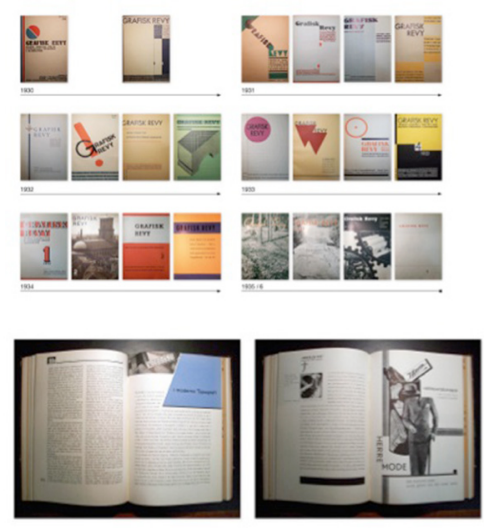

\section{The Samvirke, a Danish Bildungsverband}

Tschichold became involved after meeting Wessel in Copenhagen where he was visiting to give a series of lectures organised by Typografernes Fagtekniske Samvirke [The typographers trade-technical cooperative]. The Samvirke was an educational division of the Danish typographer's union, set up in 1931 as a Copenhagen-based group and expanded into a national organisation in 1933. Like Grafisk Revy it was formed in response to the increased interest in heightening standards and professional awareness in the trade. It sought to inform and educate on matters of style and production, areas it felt the union -with its main focus on pay and working conditions- was neglecting.

In 1934 an article presenting the growth and development of the Samvirke was published in Grafisk Revy. This also lamented the difficulties of finding likeminded organisations with which to cooperate. The Samvirke had formed a relationship with the organisation they modelled themselves on, the German Bildungsverband der Deutschen Buchdrucker [Educational Union of German Printers], but this was cut short when the Nazis banned trade unions in Germany. Having no direct counterparts in Norway or Sweden they asked individuals and organisations from either country to get in touch with them if they were interested in "developing [their] colleagues' skills and increasing the interest for the trade and its development." (Jørgensen 1934) 
Despite Grafisk Revy's and the Samvirke's shared objectives, the increased prominence of the latter was decisive in ending the former's run as a pan-Scandinavian journal. A motion was passed in the Danish typographers' union to abandon support of Grafisk Revy in favour of developing the Samvirke's bulletin Grafisk Teknik [Graphic Technique] into a monthly journal instead. Norway soon followed suit with Grafisk Kringsjå [Graphic Panorama] whilst Grafisk Revy continued as a purely Swedish journal (Wessel 1937: 734-735).

\section{The experiment ends}

The complex nature of international and national identities at play in Scandinavia is reflected in how New Typography could provide the impetus for both creation and dissolution of a Scandinavian typographers' journal. Bo Stråth, who has written extensively about identity in these countries, has argued that Scandinavian identity is an "integrated element of the national identities" - that the Scandinavian and the national are mutually reinforcing rather than opposing forces (Stråth 1994: 60). The choice of a Scandinavian platform in 1930 and a national one in 1936 is therefore not a result of a changing sense of identity as each plays to a different aspect of this identity. Nor should it be seen as an inability on New Typography's part to provide a sense of internationalism strong enough to sustain the collaboration, though an opportunity to fuse such an internationalism together with a Scandinavianism can be seen to have been missed.

Rather, I would argue that the emergence of the Samvirke exposed two internationalisms contained within Grafisk Revy, each with its own objectives. The Scandinavianism of Wessel and Nielsen was, in part at least, the result of a desire for increased bargaining power in trade disputes. With their longstanding trade union history they could not help but include 'agitation' in what would otherwise be a purely 'technical' publication. The Samvirke had no interest in such 'political' issues. Its internationalism was derived from a desire to improve the quality of the typographer's craft, and this is why it looked abroad for impulses and collaborations. Moreover, its emergence had created an unbalance in the organisational structure of the Scandinavian typographers' unions, as it had no direct Norwegian or Swedish counterpart to cooperate with. Maintaining a Scandinavian journal was therefore not vital to their interests. The Samvirke's aims could be better achieved by persuading the Danish union into developing Grafisk Teknik into a national journal instead.

\section{References}

Anon. (1931a) 'Praktisk Skandinavisme', Grafisk Revy, vol. 2, no. 1, p. 1

Anon. (1931b) 'Grafisk Revy nr. 2 Juli 1931', Norsk Trykk, vol. 5, no. 3, p. 77

Billing P., Olsson L. \& Stigendal M. (1992) "'Malmö - Our Town", Creating Social

Democracy, University Park Pennsylvania: The Pennsylvania State University Press, pp. $271-305$

Burke C. (2007) Active Literature, London: Hyphen Press

Gram M. (2006) 'När typografin blev "modern" - om modernismens genombrott i svensk typografi', Biblis, no. 34, pp. 51-63

Grass, M (2002) "'The strongest bridge between the Nordic peoples". Scandinavian archives and collections', The world in the basement, Stockholm: pp. 11-16

Hansen V. (1930) 'Elementær Typografi - den nye Variation, Grafisk Revy, vol. 1, no.

1 , pp. $13-17$

Hemstad R. (2008) Fra Indian Summer til Nordisk Vinter, Oslo: Akademisk Publisering

Hemstad R. (2010) 'Scandinavianism, Nordic Co-operation, and "Nordic Democracy"', 
Rhetorics of Nordic Democracy, pp. 179-193

Jørgensen K.A. (1934) 'Typografernes Fagtekniske Samvirke, Grafisk Revy, vol. 4, no. 1, pp. $34-36$

Lagerström H. (1927) "'Elementär typografi" - "Den nya gestaltningen" - "Den nya typografien" - "Den nya stilen"', Nordisk Boktryckarekonst, vol. 30, no. 12, pp. 131-136 Lagerström H. (1929) 'Efter trettio år', Nordisk Boktryckarekonst, vol. 28, no. 4, pp.

$457-458$

Nielsen, L.C. (1890) Finnas f. n. några utsigter för ett skandinaviskt Typografförbund?, Malmö: Author

Redaktionen [The editors] (1930) 'Till de skandinaviska kollegerna!', Grafisk Revy, vol. 1, no. 1, p. 1

Råberg, P.G. (1970) Funktionalistisk genombrott, Stockholm: Arkitekturmuseet Stråth, Bo (1994) 'The Swedish Path to National Identity in the Nineteenth Century', Nordic Paths to National Identity in the Nineteenth Century, Oslo: The Research Council of Norway

Tschichold J. (1936) 'Proportionerne i den ny Typografi, Grafisk Revy, vol. 6, no. 4, pp. 5-16 Tschichold J. (1995) The New Typography, Berkeley: University of California Press Tschichold J. (2007) 'elemental typography', Active Literature, London: Hyphen Press, p. 311 Wessel N. (1937) Svenska Typografförbundet 1887-1936, Oskarshamn:

Oskarshamnbladets boktryckeri 